\title{
Proceeding Paper \\ Physical, Chemical and Mechanical Properties of Two-Age Bambusa tuldoides Briquettes
}

\author{
Dunja Zoe Powroschnik 1, Emanuel Rangel Spadim 2, Humberto Jesus Eufrade-Junior 2, Elaine Cristina Leonello ${ }^{2}$ \\ and Saulo Philipe Sebastião Guerra ${ }^{2, *}$
}

Citation: Powroschnik, D.Z:

Spadim, E.R.; Eufrade-Junior, H.J.; Leonello, E.C.; Guerra, S.P.S. Physical, Chemical and Mechanical Properties of Two-Age Bambusa tuldoides Briquettes. Environ. Sci. Proc. 2021, 3, 85. https://doi.org/ 10.3390/IECF2020-07869

Academic Editors: Angela Lo Monaco, Cate Macinnis-Ng and Om P. Rajora

Published: 11 November 2020

Publisher's Note: M.D.P.I. stays neutral with regard to jurisdictional claims in published maps and institutional affiliations.

Copyright: (c) 2020 by the authors. Licensee MDPI, Basel, Switzerland. This article is an open access article distributed under the terms and conditions of the Creative Commons Attribution (CC BY) license (http://creativecommons.org/licenses /by/4.0/).
1 Department of Agricultural Sciences, Ecotrophology and Environmental Management (FB09), Justus Liebig University Giessen, Giessen 35390, Germany; d.zoe@gmx.de

2 School of Agriculture, São Paulo State University (Unesp), Botucatu 18610-034, Brazil; emanuel.spadim@unesp.br (E.R.S.); h.eufrade@unesp.br (H.J.E.-J.); leonelloec@gmail.com (E.C.L.)

* Correspondence: saulo.guerra@unesp.br

† Presented at the 1st International Electronic Conference on Forests - Forests for a Better Future: Sustainability, Innovation, Interdisciplinarity, 15-30 November 2020; Available online: https://iecf2020.sciforum.net.

\begin{abstract}
The use of natural resources as an energy source is a well-studied alternative to fossil fuels. Some studies present bamboo as promising biomass for energy generation, and its transformation into briquettes can be a way to take advantage of its production residues. This study's objective was to determine the physical and chemical properties of two bamboo ages (two and seven years old) of Bambusa vulgaris species to evaluate biomass quality and its briquettes for energy generation. Regarding the higher heating value, there was no difference between treatments means values, which were 17.8 and $18.2 \mathrm{MJ} \mathrm{kg}^{-1}$ for two and seven years old, respectively, and these values were slightly below those found in the literature for Bambusa spp. The mechanical durability was of low quality for both treatments at the testing conditions, so they are not recommended for briquette production. The proximate analysis results were quite near the literature and reinforce bamboo's positive qualities for biofuel usage.
\end{abstract}

Keywords: bioenergy; wood quality; bamboo

\section{Introduction}

Natural resources are sources of alternative energy concerning the decreasing fossil fuel reserves and the world's demographic growth. New biomasses are gaining momentum and are considered as viable, ecological, and sustainable options [1], as they are mostly natural resources, with the potential to generate energy by combustion.

Some studies show the positive characteristics of Bambusa spp. for use as biofuel. Two hundred fifty-eight species of bamboo native to Brazil are currently known, distributed in two families of over 12 Poaceae subfamilies: Olyreae and Bambuseae [2].

Bamboo has excellent agricultural potential and can be competitive because it produces annually and is a rustic plant that grows fast and has excellent productivity [3].

The use of bamboo has usually been limited to small businesses for handicrafts and ornaments. Despite these conditions, it is an expanding market in Brazil. However, the tradition in the bamboo production chain is still lacking, and there are knowledge and technology gaps that could allow for the use of different species [4].

Bamboo flowering is generally rare and can take tens or even hundreds of years, depending on the species, making its production harder. A possible alternative is the micropropagation of these species [5].

There is little quantitative information about the area covered with native bamboo in Brazil. A study points to areas that go from about 1.5 million hectares in southwestern 
Amazonia, dominated by native bamboo, or close to 11 million hectares if considering the ones where bamboo is present besides other plants [6].

Plantations numbers of bamboo in Brazil are imprecise. The most known private properties that publicize its area sizes point towards 50,000 to 60,000 hectares [7].

The change in the fuel characteristics of a plant, as time goes by, is known mainly for various species, primarily for ash content, density, and higher heating value [8].

Briquetting, in many cases, could be an alternative solution from biomass industrial transformation. Understand its physical and chemical properties may facilitate the understanding of the fuel to be burned and consolidate a new viable supply chain [9].

Chemical properties are related to biomass behaviour when burning in boilers, damaging its structure depending on its characteristics. The formation of slag depends on the chemical elements' ability in the ashes to fuse and how they combine. The formation of fouling is initiated with a sintering process, resulting in tough crusts that are difficult to remove over time. These characteristics are directly related to the material's chemical composition and impair thermal exchange [10]. Physical properties are also relevant; for example, when considering pressed biomasses' ability to withstand handling, transport, and storage, the mechanical durability test has to be a property commonly used to assess briquettes' quality [11].

This study aimed to determine the physical and chemical properties of two different ages of Bambusa tuldoides to assess biomass quality and its briquettes for bioenergy generation.

\section{Material and Methods}

\subsection{Material Collection and Preparation Action}

The study was conducted with Bambusa tuldoides biomass. The biomass called "New treatment" (A) is two years old, while the other "Old treatment" (B) is seven years old. Ten sampling points were randomly selected for each treatment, and ten bamboo rods were collected, from which five discs were removed according to the following position: $0 \%, 25 \%, 50 \%, 75 \%$, and $100 \%$ of the total height.

A sample of the bamboo rod was separated, weighed using a $0.1 \mathrm{~g}$ precision laboratory scale, and taken to oven drying at $65^{\circ} \mathrm{C}$ until reaching constant weight. The biomasses were prepared according to Brazilian and American standards [12,13]. After completing the drying process, the biomasses were chopped in a horizontal granulator mill into chips (three millimetres thick), then chopped in the Willey-type mill, and subsequently classified using 40 and 60 mesh sieves with a magnetic sieve shaker to classify the biomasses that were used in the analysis of the physical and chemical properties.

\subsection{Physical, Chemical, and Mechanical Properties}

The ash content and volatile matter were determined according to the American standards, and fixed carbon content was calculated by the difference between the total mass of the sample and the sum of the ash and volatile material contents [14,15]. The levels of carbon, hydrogen, nitrogen, sulfur, $(\mathrm{C}, \mathrm{H}, \mathrm{N}, \mathrm{S})$, and macronutrients, as well as the higher heating value (HHV), were analyzed in three repetitions for each treatment, using the modified Pregl-Dumas method [16] and the American standard [17], respectively. The biomass retained at 40 mesh sieve was used for briquette production, and its moisture adjusted to $12 \%$ on a dry basis.

After adjusting the moisture, 14 briquettes were produced per treatment, weighing $20 \mathrm{~g}$ and measuring $35 \mathrm{~mm}$ in diameter. A force of $11,550 \mathrm{kgf}\left(1200 \mathrm{kgf} \mathrm{cm}^{-2}\right.$ pressure) was applied to the sample for $15 \mathrm{~s}$ using a hydropneumatic press, and then the density and volumetric expansion were evaluated at $0,4,12,24,48$, and $120 \mathrm{~h}$ after pressing.

Logarithmic regression models were adjusted for the expansion of briquettes as a function of time in the form of Equation (1). 


$$
f_{i}(t)=a_{i} \ln (t)+b_{i},
$$

where $\boldsymbol{a}$ and $\boldsymbol{b}$ are the setting parameters for $f(\%)$, and $\boldsymbol{t}(\mathrm{h})$ is the time elapsed after pressing.

The volumetric expansion rates, which correspond to those derived from the $f_{i}$ functions, were used as a parameter to define the briquette as stable when they reached $0.02083 \% \mathrm{~h}^{-1}$, which corresponds to a rate of $0.5 \%$ day $^{-1}$, a value here arbitrarily determined, for calculating the moment $t$, at which stability was achieved using Equation (2).

$$
t_{i}=\frac{a_{i}}{f_{i}^{\prime}(t)^{\prime}}
$$

where $\boldsymbol{t}(\mathrm{h})$ is when the volumetric dimensional stability is achieved, $\boldsymbol{a}$ is the parameter of the adjustment $f_{i}, f_{i}^{\prime}\left(\% \mathrm{~h}^{-1}\right)$ the rate of volumetric expansion at index $i$ adjustment.

The mechanical durability was evaluated, which is related to the biomass ability to withstand adverse stacking and transport conditions, according to the Comité Européen de Normalisation's technical specifications C.E.N. standards [18] using a rotating chamber constructed into the laboratory.

\subsection{Statistical Analysis}

For statistical analysis, the statistical program R Core Team was used [19]. After confirming homogeneity of the variance of the residuals according to the Bartlett test [20], and normality by the Shapiro-Wilk test [21], an unpaired $t$-test was performed, and differences were considered being significant for $p$-value $<0.05$.

\section{Results}

For the proximate analysis, significant differences occurred for the averages of ash, being higher for the oldest bamboo treatment. The statistical analysis showed no significant difference between the two treatments for the higher heating value (HHV), volatile matter, and fixed carbon (Table 1).

Table 1. Average ash content, volatile materials, and fixed carbon.

\begin{tabular}{ccccc}
\hline Treatment & HHV $^{*}\left(\mathbf{M} . \mathbf{J}^{\mathbf{~ k g}} \mathbf{~}^{-1}\right)$ & Ash (\%) & Volatile Matter (\%) & Fixed Carbon (\%) \\
\hline A & $17.8(0.2)$ & $1.42(0.01)^{\mathrm{a}}$ & $81.56(0.08)$ & $17.01(0.08)$ \\
B & $18.2(0.3)$ & $1.56(0.01)^{\mathrm{b}}$ & $81.24(0.18)$ & $17.2(0.18)$ \\
\hline
\end{tabular}

* Higher heating value. The superscripted letters present the results of the analysis of variance (at the $95 \%$ level). Observations with a different letter are significantly different by unpaired $t$-test $(p<0.05)$.

Both bamboo ages (two and seven years old) have the same trend results for the macronutrients, following the order of $\mathrm{K}>\mathrm{N}>\mathrm{Ca}>\mathrm{S}>\mathrm{Mg}>\mathrm{P}$, as described in Figure 1 .

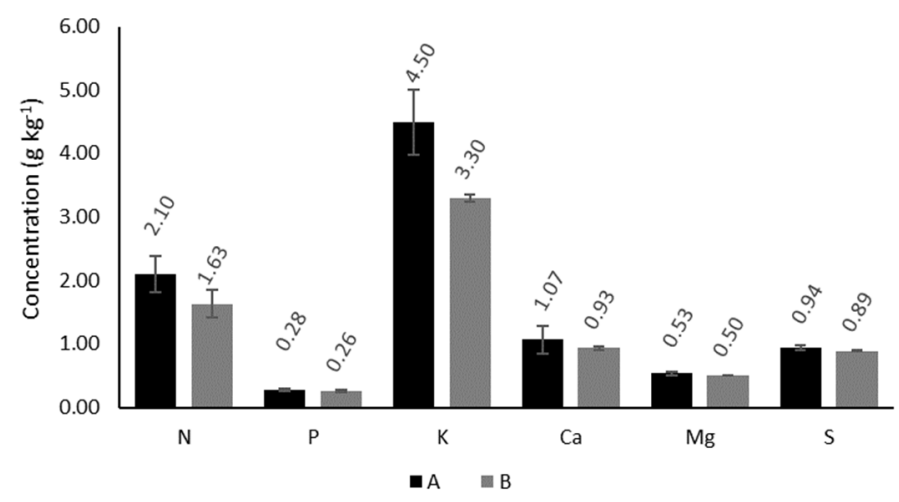

Figure 1. The concentration of six macronutrients in each treatment with standard error. 
The unpaired $t$-test showed no statistically significant difference between treatments for the ultimate analysis. The values are shown in Table 2.

Table 2. Average levels of nitrogen, carbon, hydrogen, and oxygen.

\begin{tabular}{ccccc}
\hline Treatment & $\mathbf{N ~ ( \% )}$ & $\mathbf{C ~ ( \% )}$ & $\mathbf{H ~ ( \% )}$ & O (\%) \\
\hline A & $0.22(<0.01)$ & $48.13(0.02)$ & $5.52(0.01)$ & $43.76(0.03)$ \\
B & $0.22(<0.01)$ & $47.93(0.08)$ & $5.52(0.01)$ & $43.88(0.08)$ \\
\hline
\end{tabular}

The A treatment has the most remarkable expansion, with a final mean value of $24.0 \%$ after $120 \mathrm{~h}$, and differs significantly from B with an absolute value of $19.5 \%$.

The logarithmic models' adjustments represent the volumetric expansion of the briquettes for each treatment and are shown in Figure 2 in their graphical form and by their mathematical expressions, where $i$ assumes values equal to 1 and 2 for treatments $A$ and $B$, respectively.

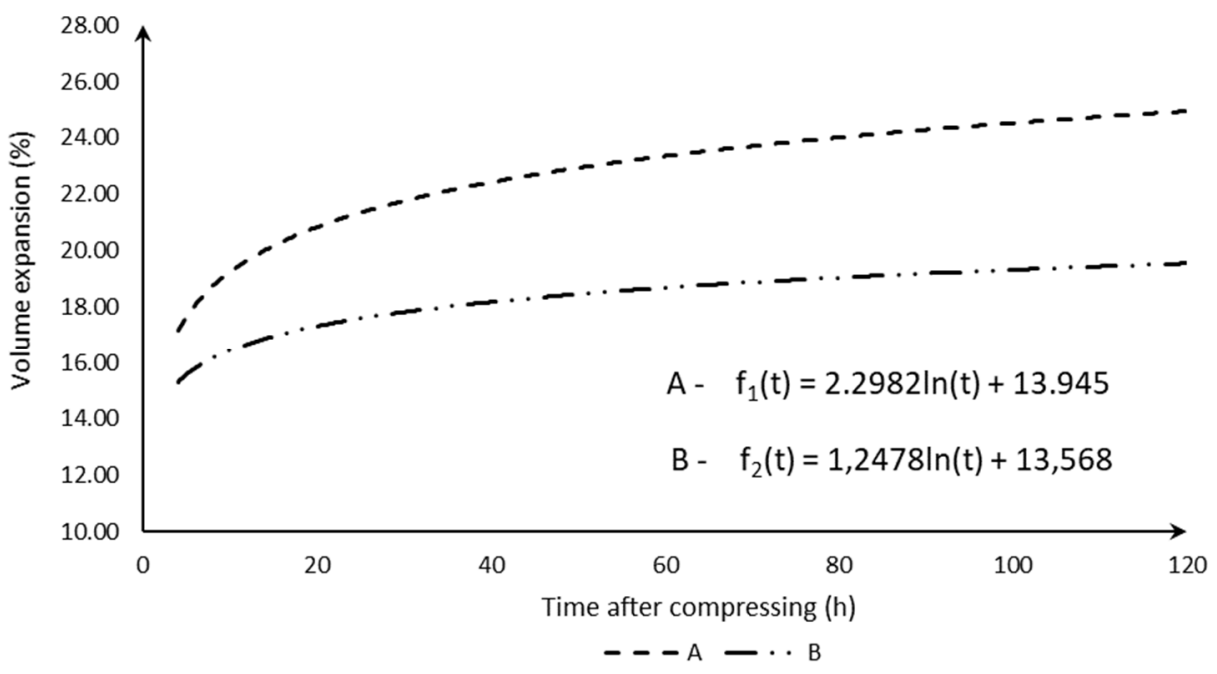

Figure 2. Volumetric expansion of briquettes.

For all treatments, the briquettes' durability was extremely low, according to the standard used classification. Treatments B and A's briquettes crumbled almost wholly. Only a range from $0.89 \%$ to $6.18 \%$ of the material was retained through the $3 \mathrm{~mm}$ sieve. The average values of the results are in Table 3.

Table 3. Results of the mechanical durability test.

\begin{tabular}{ccc}
\hline Treatment & Mechanical Durability (\%) & Moisture (\%) \\
\hline A & $2.3(1.9)$ & $9.3(0.1)$ \\
B & $3.1(1.6)$ & $9.6(0.3)$ \\
\hline
\end{tabular}

Standard errors are in parentheses.

\section{Discussion}

Ash has an important implication on harvesting or industrial operations. Bamboo ash content varies according to species and management, equal to or less than $1 \%[22,23]$. In the present study, where different bamboo ages were sampled, a higher ash content found is still within limits described [24,25].

Macronutrients influence the melting of ash, such as $\mathrm{Ca}$ and $\mathrm{Mg}$, which generally increase the melting point of ash, and $\mathrm{K}$, which decreases it, affecting the sintering process. The level of S can, along with other elements, contribute to the boilers' corrosion [26]. Compared to the average annual values [27], this experiment obtained higher $\mathrm{N}, \mathrm{P}, \mathrm{K}$, and 
Ca values in all treatments. An increasing age led to a decrease in N, P, K, and Ca and increased $\mathrm{Mg}$ concentration. The relatively high value of $\mathrm{P}$ stands out for being considered an essential element due to its characteristic of facilitating the formation of high melting point $\mathrm{K}-\mathrm{Ca} / \mathrm{Mg}$ phosphate compounds, which, combined with the low ash content, would characterize bamboo as a promising biofuel for not presenting severe sintering at temperatures below $1000{ }^{\circ} \mathrm{C}$ [23].

Taking the $\mathrm{C}, \mathrm{H}$, and $\mathrm{O}$ averages values presented for 50 bamboo species (43.06-46.58\% for $\mathrm{C}, 5.16-7.6 \%$ for $\mathrm{H}$, and $46.02-50.35 \%$ for O), it can be stated that the values found in this work are either within or very close to those found in the literature [28].

According to Table 1, the HHV values found were slightly lower than those found in the literature. Considering data from several pieces of research, such as mean HHV values of 19.4 $\mathrm{MJ} \mathrm{kg}^{-1}$ for Bambusa spp [23], mean HHV values were between 19.09 and $19.57 \mathrm{MJ} \mathrm{kg}^{-1}$ for the species Phyllostachys nigra, Phyllostachys bambusoides, and Phyllostachys bissetii [22], and B. vulgaris, with an average value of $19.12 \mathrm{MJ} \mathrm{kg}^{-1}$, which is slightly below average [3]. On the other hand, it is possible to track research data with HHV values closer to those of this study, $18.7 \mathrm{MJ} \mathrm{kg}^{-1}$ for $B$. tuldoides, and $17.6 \mathrm{MJ} \mathrm{kg}^{-1}$ for B. vulgaris [29]. HHV of eucalyptus wood (19.0 MJ kg-1) [30] is similar to bamboo, while HHV of rice hulk, wheat straw, timothy grass, and sugar cane bagasse (HHV between 16.3 and $17.3 \mathrm{MJ} \mathrm{kg}^{-1}$ ) [31-33] is slightly lower. HHV of pinewood is $20.71 \mathrm{MJ} \mathrm{kg}^{-1}$, which is relatively high [34] compared to the HHV of bamboo and the other lignocellulosic species mentioned above.

Although many bamboo properties are similar to eucalyptus, the final average expansion varied from $19.5 \%$ up to $24 \%$, which is greater than those of experiments made with eucalyptus [9], which presented an average of $9.7 \%$ for the stem of Eucalyptus urophylla $\times$ Eucalyptus grandis. The high expansion and low durability of the briquettes confirm the propositions [35], which suggest that briquettes with greater dimensional stability generally have more excellent mechanical resistance. The briquettes were submitted to the durability test with low moisture, and it is known that this property significantly influences the mechanical durability [36], so this characteristic may have contributed to bad results. The mechanical durability of briquettes fell far short of that recommended by EN 14961-2 [37], requiring a $96.5 \%$ durability as a minimum condition for commercialization.

\section{Conclusions}

As the proximate analysis results show, both treatments had relatively low ash content, so bamboo could be considered suitable for burning in boilers since the lower ash content provides less corrosion and less cleaning time than other biomasses.

The ultimate analysis showed expected results, with no impeditive characteristics for burning the biomass.

There was no difference between treatments regarding the higher heating value, and their values were slightly below those found in the literature for Bambusa spp.

Even though bamboo has positive characteristics for burning processes, the two studied treatments' briquettes performed poorly and are not recommended to produce briquettes in the tested condition.

Moisture is a determining factor in the briquette's mechanical durability and may have determined the low mechanical durability.

Author Contributions: Conceptualization, E.R.S. and H.J.E.-J.; methodology, S.P.S.G. and H.J.E.-J.; software, D.Z.P. and E.R.S.; validation, D.Z.P. and E.R.S.; formal analysis, D.Z.P. and E.R.S.; investigation, D.Z.P. and E.R.S.; data curation, E.R.S.; writing-original draft preparation, D.Z.P. and E.R.S.; writing - review and editing, all; supervision, S.P.S.G. and H.J.E.-J.; project administration, S.P.S.G.; funding acquisition, S.P.S.G. All authors have read and agreed to the published version of the manuscript.

Funding: DAAD RISE Worldwide Program for sponsoring Dunja's internship in Brazil. 
Data Availability Statement: Data available on request due to restrictions, e.g. privacy or ethical. The data presented in this study are available on request from the corresponding author. The data are not publicly available due to being part of a bigger study in development.

Acknowledgments: The authors would like to acknowledge the Laboratory of Agroforest Biomass and Bioenergy (LABB-FCA/UNESP) at the Institute of Bioenergy Research (IPBEN/UNESP), and APTA-Tatuí/SP.

Conflicts of Interest: The funders had no role in the design of the study, in the collection, analyses, or interpretation of data, in the writing of the manuscript, or in the decision to publish the results.

\section{References}

1. Mazzetto, S.E.; Costa Júnior, A.E.; Lomonaco, D. Fibras de bambu como carga de reforço em materiais compósitos: Fonte alternativa, econômica e sustentável. In Bambus No Brasil, 1st ed.; Drumond, P.M., Wiedman, G., Eds.; Embrapa: Rio de Janeiro, Brazil, 2017; pp. 526-527.

2. Filgueiras, T.S.; Viana, P.L. Bambus brasileiros: Morfologia, taxonomia, distribuição e conservação. In Bambus no Brasil, 1st ed.; Drumond, P.M., Wiedman, G., Eds.; Embrapa: Rio de Janeiro, Brazil, 2017; pp. 10-28.

3. Balduino Junior, A.L.; Balduino, T.Y.; Friederichs, G.; Da Cunha, A.B.; Brand, M.A. Potencial energético de colmos de bambu para uso industrial e doméstico na região sul do Brasil. Cienc. Rural 2016, 46, 1963-1968.

4. Afonso, D.G. Bambu Nativo (Guadua spp.): Alternativa de Desenvolvimento Econômico e Sustentável Para o Estado do Acre; UFPR: Curitiba, Brazil, 2011.

5. Singh, R.; Sanjay Kalia, S.; Dalal, S.; Dhawan, A.K.; Kalia, R.K. Limitations, progress and prospects of application of biotechnological tools in improvement of bamboo-A plant with extraordinary qualities. Physiol. Mol. Biol. Plants 2013, $19,21-41$.

6. Carmo, L.F.Z.; Amaral, E.F.; Bardales, N.G. Ocorrência, biomassa, perdas e explroação de bambu em florestas da Amazônia no Acre, Brasil. In Bambus No Brasil, 1st ed.; Drumond, P.M., Wiedman, G., Eds.; Embrapa: Rio de Janeiro, Brazil, 2017 ; pp. 10-28.

7. Santi, T. Bambu para toda obra. O Papel 2015, 76, 22-33.

8. Brito, A.S.; Silva, J.G.M.; Vidaurre, G.B.; Trugilho, P.F.. Influência da idade nas propriedades da madeira de eucalipto. In Qualidade da Madeira de Eucalipto Proveniente de Plantações No Brasil, 1st ed.; Silva, G.B., Moulin, J.G.M., Carneiro, J.C., Eds.; Edufes: Vitória, Brazil, 2020; Volume 1, pp. 154-196.

9. Eufrade-Junior, H.J.; Nakashima, G.T.; Yamaji, F.M.; Guerra, S.P.S.; Ballarin, A.W. Eucalyptus short-rotation coppice for solid fuel production. Ind. Crops Prod. 2017, 108, 636-640.

10. Vamvuka, D.; Trikouvertis, M.; Pentari, D.; Alevizos, G. Evaluation of ashes produced from fluidized bed combustion of residues from oranges plantations and processing. Renew. Energy 2014, 72, 336-343.

11. Kaliyan, N.; Morey, R.V. Factors affecting strength and durability of densified biomass products. Biomass Bioenergy 2009, 33, 337-359.

12. ABNT NBR 14660. Madeira-Amostragem e Preparação para Anális; Assoc. Bras. Normas Técnicas: Rio de Janeiro, Brasil, 2004.

13. ASTM 1757-01. Standard Practice for Preparation of Biomass for Compositional Analysis; Am. Soc. Test Mater: West Conshohocken, PA, USA, 2011.

14. ASTM E1755-01. Standard Test Method for Ash in Biomass; Am. Soc. Test Mater: West Conshohocken, PA, USA, 2015.

15. ASTM. E871-82. Standard Test Method for Moisture Analysis of Particulate Wood Fuels; Am. Soc. Test Mater: West Conshohocken, PA, USA, 2006.

16. Malavolta, E.; Vitti, G.C.; Oliveira, S.A. Evaluation of Plant Nutrient Status: Principles and Their Application, 2nd ed.; Associação Brasileira para Pesquisa da Potassa e do Fosfato: Piracicaba, Brazil, 1997; p. 319.

17. ASTM E711-87. Standard Test Method for Gross Calorific Value of Refuse-Derived Fuel by the Bomb Calorimeter; Am Soc Test Mater: West Conshohocken, PA, USA, 2004.

18. 15210-1 CEN/TS. Solid Biofuels-Determination of Mechanical Durability of Pellets and Briquettes - Part 1; Pellets. Eur. Comm. Stand.: Brussels, Belgium, 2009.

19. R.C. Team. R: A Language and Environment for Statistical Computing; R Foundation for Statistical Computing: Viena, Austria, 2016.

20. Bartlett, M.S. Properties of sufficiency and statistical tests. Proc. R. Soc. Lond. 1937, 160, 268-282.

21. Shapiro, S.S.; Wilk, M.B. An analysis of variance test for normality (Complete Samples), Biometrika 1965, 52, 591.

22. Scurlock, J.M.O.; Dayton, D.C.; Hames, B. Bamboo: An overlooked biomass resource? Biomass Bioenergy 2000, 19, $229-244$.

23. Zhu, Y. Ash fusion characteristics and transformation behaviors during bamboo combustion in comparison with straw and poplar. Energy Fuels 2018, 32, 5244-5251.

24. Marafon, A.C.; Santiago, A.D.; Amaral, A.F.C.; Bierhals, A.N.; Paiva, H.L.; Guimarães, V.S. Poder Calorífico do Capim- Elefante, Embrapa 2016, 1, 29.

25. Demirbas, A. Potential applications of renewable energy sources, biomass combustion problems in boiler power systems and combustion related environmental issues. Prog. Energy Combust. Sci. 2005, 31, 171-192.

26. Obernberger, I.; Brunner, T.; Bärnthaler, G. Chemical properties of solid biofuels-significance and impact. Biomass Bioenergy 2006, 30, 973-982. 
27. Shanmughavel, P.; Francis, K. Biomass and nutrient cycling in bamboo (Bambusa bambos) plantations of tropical areas. Biol. Fertil. Soils 1996, 23, 431-434.

28. Pattanayak, S.; Loha, C.; Hauchhum, L.; Sailo, L. Application of MLP-ANN models for estimating the higher heating value of bamboo biomass. Biomass Convers. Biorefinery 2020, 1-10, doi:10.1007/s13399-020-00685-2.

29. Brito, J.O.; Tomazello Filho, M.; Salgado, A.L.B. Produção e caracterização do carvão vegetal de espécies e variedades de bambu. Instituto de Pesquisas e Estudos Florestais IPEF 1987, 36, 13-17.

30. Soares, V.C.; Bianchi, M.L.; Trugilho, P.F.; Höfler, J.; Pereira, A. Análise das propriedades da madeira e do carvão vegetal de híbridos de eucalipto em três idades. Cerne 2015. 21, 191-197.

31. Sonil, N.; Pravakar, M.; Pant, K.K.; Naik, S.; Kozinski, J.A.; Dalai, A.K. Characterization of North American Lignocellulosic Biomass and Biochars in Terms of their Candidacy for Alternate Renewable Fuels. Bioenergy Res. 2013, 2, $663-677$.

32. Diniz, J.; Cardoso, A.L.; Stahl, J.A.; Villetti, M.A.; Martins, A.F. Poder Calorífico da Casca de Arroz, Caroço de Pêssego, Serragem de Eucalipto e de seus Produtos de Pirólise. Ciência Nat. 2004, 26, $25-32$.

33. Jenkins, B.M. Fuel properties for biomass materials. Appl. Manag. Energy Agric. Role of Biomass Fuels 1990, 1, $21-23$.

34. Martinez, C.L.M.; Sermyagina, E.; Carneiro, A.C.O.; Vakkilainenb, E.; Cardoso, M. Production and characterization of coffeepine wood residue briquettes as an alternative fuel for local firing systems in Brazil. Biomass Bioenergy 2019, $123,70-77$.

35. Silva, D.A.; Yamaji, F.M.; Barros, J.L.; Róz, A.L.; Nakashima, G.T. Caracterização de biomassas para a briquetagem. Floresta 2005, 45, 713-722.

36. Al-Widyan, M.I. Physical durability and stability of olive cake briquettes. Can. Biosyst. Eng./Le Genie Des Biosyst. Au Can. 2002, $44,1-41$.

37. EN 14961-2, 14961-14962: 2011-09. Solid Biofuels-Fuel Specif. Classes; Eur. Comm. Stand.: Brussels, Belgium, 2011. 